\title{
Store Image Factors Influencing Store Choice among Sportswear Consumers: Baseline Findings from South Africa
}

\author{
Manilall Dhurup \\ Faculty of Management Sciences, Vaal University of Technology \\ Private Bag X021, Vanderbijlpark, 1900, South Africa \\ Email: royd@vut.ac.za \\ Chengedzai Mafini \\ Faculty of Management Sciences, Vaal University of Technology \\ Private Bag X021, Vanderbijlpark, 1900, South Africa \\ Email: chengedzai@hotmail.com \\ Ryan Lesetja Mathaba \\ Faculty of Management Sciences, Vaal University of Technology \\ Private Bag X021, Vanderbijlpark, 1900, South Africa \\ Email: ryanm@uj.ac.za
}

Doi:10.5901/mjss.2013.v4n14p359

Abstract

The aim of this study was to examine store image factors influencing store selection choice among consumers of sports apparel in South Africa. The study used a two section questionnaire to elicit responses from a total of 489 conveniently selected sportswear consumers based in three shopping malls in the Gauteng Province of South Africa. The respondents' demographic data were analysed using descriptive statistics. Exploratory factor analysis was used to identify store image factors influencing store choice. The mean score ranking technique was employed to compare the importance of the extracted factors. The Mann-Whitney $U$ test was used to test for the influence of gender differences in store choice. Six factors influencing the store choice of sportswear consumers were identified. These were sales assistance, store atmospherics, store appeal, in-store induced appeals, promotion/brand availability and store accessibility. Among these factors, sales assistance emerged as the most important factor influencing store choice of sportswear consumers. The study also revealed that gender differences do not significantly influence store selection choice. Using the findings of the study, marketers of sports apparel may be able to increase the patronage levels in their stores by expediting the six factors identified in this study.

Keywords: Store image, store choice, sportswear, South Africa

\section{Introduction and Background to the Study}

Store choice and patronage are among topical issues that have been widely studied across many settings (Sinha, Banerjee \& Uniyal, 2002:13). However, there remains vast scope for research, given that the retailing environment is subject to unpredictable tectonic shifts, which lead to evolving shopper expectations and a realignment of the choice among a set of stores (Sinha \& Banerjee, 2004:482). The prevailing socio-demographic changes in current consumer markets, the expanding number of dual-income and single parent households and the increasing number of computerliterate consumers have significantly altered consumer expectations and demands during their shopping experiences (Kim, 2002:595). As a result, consumers of today usually make methodical decisions regarding the stores they choose to patronise (Oh, Fiorito, Cho \& Hofacker, 2008:247). These decisions are influenced by various individual and social factors (Lamb, Hair, McDaniel, Boshoff \& Terblanche, 2004:75). The image of a retail outlet is important in such a decision because the consumer may be seeking a particular brand or quality of merchandise, specific services such as credit or delivery, an attractive outlet, courteous employees, and an outlet where consumers with similar lifestyles are likely to shop (Foxall \& Yani-de-Soriano, 2005:524). In addition, the store appearance, its employees and promotional materials offer noticeable cues to consumers that contribute to their perception of a store's image (Amine \& Cadenat, 
2003:486).

It is against this backdrop that this study set out to examine factors influencing store choice among sportswear consumers in South Africa. According to McKeever (2011:3) store selection criteria tend to be situation specific and are typically subjected to shifts over time. In addition, there are many competing choices and a lack of clarity associated with the issue of competing stores. Different store types or categories present consumers with an array of choices when selecting the store in which to shop. It is also interesting that the majority of store environment research has not examined the key issues regarding how different store environment cues collectively shape consumers' merchandise value perceptions and how those perceptions, in turn, influence store patronage (Baker, Parasuraman, Grewal \& Voss, 2002:120). As argued by Broekemier, Marquardt and Gentry (2008:60), retail patronage intentions have been found to be more highly correlated with consumers' beliefs about the image of a retail service environment than with the merchandise quality, general price level and product selection. This constellation of views attracts the need to explore consumer shopping behaviour as well as purchase drivers in apparel stores.

This study is significant in that an understanding of the dynamics surrounding consumers' choice may assist retailers in becoming more responsive to consumers' need for information during their search and evaluation efforts (Carpenter \& Brosdahl, 2011:886). Such knowledge may also assist in distinguishing the elements that contribute to customer satisfaction from those that sustain store loyalty and, thereby, suggest an appropriate allocation of resources (Blackwell, Miniard and Engel (2006:85). As suggested by Karpova, Hodges and Tullar (2007:117), a lack of knowledge about the needs and wants of consumers can also create difficulties for retailers. Moreover, understanding how consumers assess quality and the factors influencing their purchase decisions may also aid retailers and marketers in selecting what merchandise to stock as well as in promoting their business (De Klerk \& Lubbe, 2008:37). Another notable fact is that South Africa has some of the largest retail enterprises in the world, and is Africa's principal economy. This adds an impetus to the study, as it presents a need to collect updated information on consumer behaviour within this market.

\section{Review of Related Literature}

Martineau (1958:54) was among the first scholars to define store image as "a store's personality and the way in which the store is defined in the consumer's mind". This definition is authoritative because it clearly clarifies how the consumer views the store as well as what the consumer feels about the store (Li, 2008:4). However, in recent studies by scholars such as Kardes, Cline and Cronely (2011:71) and Lusch, Dunne and Carver, (2011:101) store image was defined simply as a set of attributes deemed important by consumers. Saraswat, Mammen, Aaja and Tewari (2010:168) also redefined store image as the symbolic, experiential expression of the manner in which consumers see or visualise a store. A common thread in these definitions is that store image pertains to the perceptions of consumers about a particular store.

Prasad and Aryasri (2011:80) emphasise that store image is an important factor in two types of decisions relevant to developments in retail markets; namely, consumer decisions (where and when to shop) and retailer decisions (when, where and how to operate their stores). Retail stores have images of their own that serve to influence the perceived quality of the products they carry and the decisions of consumers pertaining to where to shop (Schiffman \& Kanuk, 2009:185). It is important for retailers to establish, communicate and maintain the firm's image in order to position it in the customers' minds (Berman \& Evans, 2013:668). Du Preez, Visser and Van Noordwyk (2008b:76) also found that the formation of the store image relies on the perception of a store, which differs according to retailers, products and target markets.

Previous research has analysed the extent to which image attributes affect store choice behaviour. Visser, du Preez and Van Noordwyk (2006:60) for example, found that merchandise and clientele are the most important image dimensions that affect respondents. Koksal (2007:79) discovered that product, pricing, methods of payment, personnel and store convenience are deemed most important attributes when choosing a grocery store. Hassan, Muhammad and Abu Bakar (2010:180) found that consumers tend to choose a store that offers reasonable prices, a variety of merchandise and personalised services. Venter and Dhurup (2005:432) also found that customers attach great importance to the atmospheric variable (physical aspects), the reliability and the policies of the retailer.

Visser et al. (2006:61) emphasised that differences exist in the perceived prominence of retail store image amongst customers when making buying decisions. Pan and Zinkhan (2006:239) highlighted the following retail environment factors: physical location, parking facilities, check-out speed, and store atmosphere as crucial for consumers searching for a traditional retail store. Hsu, Huang and Swanson (2010:126) and Chang and Luan (2010:523) recognised that convenience factors, merchandise, store ambience, services personnel and marketing attractiveness are 
key dimensions used by a consumer when evaluating store image. However, Van Waterschoot, Sinha, Van Kenhove and De Wulf (2008:196) found price, reputation and quality to be the key dimensions associated with the consumer's perception of fashion store image. Chen-Yu and Seock (2002:71) studied "adolescents store selection criteria", and their findings showed that sexual attraction and recognition were motives behind selecting a certain clothing store. The results of Moore and Carpenter's (2006:270) study reveal that price, quality and selection of merchandise were ranked as the most important store attributes to male consumers when deciding upon a clothing store. Additionally, Kwon and Lennon (2011:254) found that service, merchandise and store environment are the prominent attributes for female shoppers when buying apparel brands. From the foregoing discussion, it seems that various store image variables perform an essential role in store selection. Furthermore, it also seems that there are variations on the number and types of variables that come into play in store selection.

\section{Research Method}

For the purposes of this study, the quantitative approach using the survey technique was chosen. This approach was selected because it enables the sizable representation of the selected population, has an organised procedure for gathering data, is also very specific, and ensures that formulation of data collected follows an orderly procedure (Burns \& Bush, 2010:235).

\subsection{Participants}

In this study, the sample consisted of sportswear shoppers, 18 years and older who patronise three shopping malls; namely, Protea Gardens Mall, Southgate Mall and Jabulani Mall, which are located in Soweto Township, Gauteng Province, South Africa. Since it was difficult to obtain a list of sportswear shoppers, respondents were selected using the convenience sampling technique. Using the historical sample size approach, in which several previous studies (Oates, Shufeldt \& Vaught, 1996; Sherman, Mathur \& Smith, 1997; Kucukemiroglu, 1999; Morschett, Swoboda \& Foscht, 2005; Carpenter \& Moore, 2006; Wirtz, Mattila \& Tan, 2007) were used as reference points, the initial sample size was pegged at 700 respondents.

\subsection{Instrumentation and data Collection Procedures}

In this study, data were collected using a self administered structured questionnaire. Specifically, a mall intercept survey was conducted for this study. This type of survey was chosen due its low cost, the ability to yield accurate responses and the fact that data is easily obtainable (Wiid \& Diggins, 2009:114). The questionnaire used in this study was stratified into two sections. Section A consisted of 41 questions based on consumer store selection criteria. These questions were placed on a seven point Likert scale anchored by 1 denoting extremely unimportant and 7 denoting extremely important. Additionally, these questions were adapted from previous studies undertaken by Lu and Rucker (2006:46), Van der Vyver (2008:148), Rigopoulou and Tsiotsou (2008:987) and Reutterer \& Teller (2009:701). Section B consisted of five dichotomous and multiple-choice questions based on shopping orientation and demographic attributes.

Administration of questionnaires was conducted on-site between the fifth of November and the third of December, 2012. Four trained fieldworkers assisted in the collection of data. In order to ensure an efficient, accurate and effective data were obtained, the researchers were available to provide fieldwork supervision. Furthermore, participation in the survey was strictly voluntary. Out of the 700 questionnaires that were initially distributed, 489 questionnaires were successfully completed and eventually used in the actual data analysis.

\subsection{Data Analysis}

The data were analysed in the following ways: a descriptive analysis of the sample composition was undertaken and factor analysis was undertaken to establish the factors that contributed to store selection among sportswear consumers. In addition, a comparative analysis of the mean-scores was employed to test the importance of the factors relative to each other. The Mann-Whitney U Test was then used to test for differences between the identified dimensions of store choice and gender in order to establish whether males and females differ in terms of the of the extracted store choice dimensions. These analyses were conducted using the Statistical Packages for the Social Sciences (SPSS - version 21.0). 


\section{Results}

\subsection{Demographic Characteristics of Respondents}

The demographic characteristics of respondents are illustrated in Table 1.

Table 1: Demographic information of the respondents

\begin{tabular}{|c|c|c|c|c|}
\hline Variable & Categories & $\mathrm{N}$ & $\mathrm{n}$ & $\%$ \\
\hline \multirow{2}{*}{ Gender } & Males & 489 & 250 & 51.0 \\
\hline & Females & 489 & 239 & 49.0 \\
\hline \multirow{6}{*}{ Age Group } & Less than 20yrs & 489 & 85 & 17.4 \\
\hline & Between 20- 29 years & 489 & 221 & 45.2 \\
\hline & Between 30-39 years & 489 & 123 & 25.2 \\
\hline & Between $40-49$ years & 489 & 44 & 9.0 \\
\hline & Between $50-59$ years & 489 & 14 & 2.9 \\
\hline & Over 59 years & 489 & 2 & 0.4 \\
\hline \multirow{4}{*}{ Marital status } & Single & 489 & 328 & 67.1 \\
\hline & Married & 489 & 125 & 25.6 \\
\hline & Divorced & 489 & 25 & 5.1 \\
\hline & Widowed & 489 & 10 & 2.0 \\
\hline \multirow{6}{*}{ Annual income } & $<\mathrm{R} 100000$ & 489 & 284 & 58.1 \\
\hline & R100 000- R200 000 & 489 & 140 & 28.6 \\
\hline & R200 000- R300 000 & 489 & 46 & 9.4 \\
\hline & R300 000- R400 000 & 489 & 12 & 2.5 \\
\hline & R400 000- R500 000 & 489 & 5 & 1.0 \\
\hline & $\geq \mathrm{R} 600000$ & 489 & 2 & 0.4 \\
\hline \multirow{9}{*}{$\begin{array}{c}\text { Sportswear items last } \\
\text { purchased }\end{array}$} & Sneakers (takkies) & 489 & 170 & 34.8 \\
\hline & Track suits & 489 & 87 & 17.8 \\
\hline & Shirts/Golf T-shirts & 489 & 86 & 17.6 \\
\hline & Jackets & 489 & 39 & 8.0 \\
\hline & Pants & 489 & 46 & 9.4 \\
\hline & Headgear & 489 & 14 & 2.9 \\
\hline & Underwear & 489 & 17 & 3.5 \\
\hline & $\begin{array}{l}\text { Accessories(e.g. sunglasses, watches \& } \\
\text { sweat bands) }\end{array}$ & 489 & 6 & 1.23 \\
\hline & Other (e.g. vests \& tights) & 489 & 24 & 4.9 \\
\hline
\end{tabular}

As illustrated in Table 1, 51\% of respondents $(n=250)$ were male whereas $49 \%(n=239)$ were female. The majority of the respondents (45.2\%; $n=221$ ) were aged between 20 and 29 years. In terms of marital status, approximately $67.1 \%$ $(n=328)$ of the respondents were single. Additionally, the largest group of respondents (58.1\%; $n=284)$ earned less that R100 000 per annum. Most respondents $(34.8 \% ; n=170)$ purchased sneakers (takkies) more than other types of sports apparel.

\subsection{Validity and Reliability}

Validity refers to the extent to which differences in scores on a measuring instrument reflect true differences among individuals, groups, or situations in the characteristics that it seeks to measure, or true differences in the same individual, group, or situation from one occasion to another (Churchill \& Brown, 2007:271). To ascertain the content and face validity of the instrument, the initial questionnaire was reviewed by three academics whose field of expertise is marketing. Furthermore, the questionnaire was pilot tested using a group of 40 conveniently selected respondents, as prescribed by Zikmund (2003:330). Using the feedback from the three reviewers as well as the pilot study, minor changes were made to the questionnaire, thereby ensuring that the eventual questionnaire was clearer and more suitable for data collection purposes. Construct validity was assessed through the reliabilities of the factors and was measured using Cronbach alpha coefficient (refer to Table 3). Reliability refers to the extent to which a scale produces consistent results if repeated measurements are made (Churchill \& Brown, 2007:271). For the purpose of this study, the Cronbach alpha reliability was 
used because it gives an indication of the average correlation among all items that makes up the scale. Notably, the overall Cronbach alpha for this study was 0.76 (refer to Table 3), which is above the 0.70 threshold recommended by Hair et al. (2010:210).

\subsection{Exploratory factor analysis}

The purpose of this study was to examine the store image factors influencing store selection among sportswear consumers. These factors were identified using exploratory factor analysis. Exploratory factor analysis is an approach used to identify underlying dimensions among a set of factors (Aaker, Kumar \& Day, 2007:562). Scale purification was conducted in which low factor loadings, cross-loadings and low communalities were eliminated in order to improve "interpretability of the factor structure" (Malhotra 2010:643). A minimum cut-off of 0.50 was used on the variable loadings. This is consistent with the Hair et al.'s (2010:210) suggestion that factor loadings greater than \pm 0.30 are considered to meet the minimum levels, loadings of \pm 0.40 are considered important, and loading of \pm 0.50 and greater are considered more important.

The Bartlett's test was significant at $p<0.000$ inferring that the data set is not an identity matrix with zero correlations (i.e. variables are correlated) thus confirming that a factor analysis procedure could be applied in the study. Furthermore, the Bartlett's test produced a chi square value $\left(X^{2}\right)$ of $12318.601(\mathrm{df}=630)$ and a KMO value of 0.958 $(>0.50)$ which also confirmed that the data were suitable for factor analysis. The results of the rotated component matrix, percentage of variance explained by each factor, cumulative percentage of variance and eigen value criterion were assessed. Finally, a six-factor structure was developed as the items were logically associated with the underlying factors. The rotated factor loading matrix illustrating the resultant factors and their eigen values are reported in Table 2.

Table 2: Rotated factor loading matrix: store selection criteria

\begin{tabular}{|c|c|c|c|c|c|c|c|}
\hline $\begin{array}{l}\text { Item } \\
\text { Code }\end{array}$ & Item Description & F1 & F2 & F3 & F4 & F5 & F6 \\
\hline A1 & Sales personnel appearance & .561 & .408 & .167 & .025 & .158 & .138 \\
\hline A2 & The willing of sales personnel to help customers & .827 & .163 & .168 & .152 & .096 & .158 \\
\hline $\mathrm{A} 3$ & The treatment by the sales personnel towards customers in the store & .833 & .144 & .184 & .152 & .126 & .158 \\
\hline A4 & The personal attention displayed by sales personnel & .725 & .295 & .177 & .285 & .056 & .113 \\
\hline A5 & The ability of sales personnel to respond to customer requests & .767 & .235 & .174 & .204 & .068 & .205 \\
\hline A6 & The fashionability of the store interior & .381 & .692 & .203 & .107 & .149 & .155 \\
\hline A7 & The style of decor in the store & .287 & .766 & .245 & .170 & .159 & .153 \\
\hline A8 & The attractiveness of the decor in the store & .253 & .761 & .215 & .159 & .159 & .163 \\
\hline A9 & The colours used in the store & .118 & .700 & .262 & .229 & .178 & .161 \\
\hline A10 & The efficiency of the sales personnel in the store & .268 & .596 & .067 & .361 & .091 & .244 \\
\hline A12 & The suitability of finishing material in the store & .342 & .501 & .307 & .326 & .175 & .118 \\
\hline A14 & The social class appeal of the store & .213 & .540 & .257 & .173 & .187 & .176 \\
\hline A15 & The variety of brands carried by the store. & .338 & .224 & .557 & .197 & .299 & .226 \\
\hline A16 & The appeal of in-store displays & .285 & .319 & .648 & .155 & .181 & .218 \\
\hline A17 & The appeal of the entrance of the store. & .196 & .286 & .778 & .163 & .126 & .169 \\
\hline A18 & The appeal of the exit of the store. & .165 & .242 & .810 & .112 & .109 & .170 \\
\hline A19 & The proximity of the store in relation to other stores & .260 & .180 & .545 & .213 & .098 & .349 \\
\hline A22 & The attractiveness of exterior store design & .043 & .303 & .533 & .167 & .212 & .401 \\
\hline A23 & The store layout & .066 & .368 & .428 & .162 & .203 & .588 \\
\hline A24 & The ease at which merchandise can be found in the store & .259 & .195 & .225 & .298 & .226 & .591 \\
\hline $\mathrm{A} 25$ & The ease of movement in the mall where the store is situated & .290 & .160 & .127 & .258 & .186 & .681 \\
\hline $\mathrm{A} 26$ & The amount of walking required within stores & .184 & .128 & .263 & .126 & .101 & .697 \\
\hline $\mathrm{A} 27$ & The store operating hours & .338 & .160 & .264 & .308 & .278 & .467 \\
\hline A28 & The accessibility of store entrance/exit & .275 & .217 & .407 & .165 & .215 & .506 \\
\hline A29 & The position of aisles in the store & .186 & .377 & .337 & .223 & .209 & .531 \\
\hline A31 & The courteous approach to customers by sales personnel & .451 & .041 & .205 & .537 & .115 & .316 \\
\hline A32 & The number of sales personnel & .303 & .171 & .218 & .618 & .079 & .251 \\
\hline A33 & The availability of gift vouchers & .106 & .318 & .096 & .703 & .142 & .220 \\
\hline A34 & The credibility of in-store advertising & .327 & .240 & .107 & .650 & .170 & .265 \\
\hline
\end{tabular}




\begin{tabular}{|c|c|c|c|c|c|c|c|}
\hline $\mathrm{A} 35$ & The sales with marked-down prices & .176 & .246 & .162 & .672 & .183 & .236 \\
\hline A36 & The timely announcement of sales & .212 & -.074 & .270 & .479 & .550 & -.166 \\
\hline A37 & The availability of special offers & .133 & .033 & .237 & .519 & .595 & -.05 \\
\hline A38 & My ability to identify with the store & .078 & .171 & .197 & .094 & .771 & .12 \\
\hline A39 & The availability of exclusive merchandise (limited number manufactured) & .177 & .138 & .066 & .126 & .705 & .23 \\
\hline $\mathrm{A} 40$ & The availability of branded labels (e.g. Nike) & .141 & .201 & .068 & .249 & .695 & \\
\hline A41 & The physical appearance of sales personnel & -.050 & .208 & .063 & -.057 & .648 & .20 \\
\hline \multicolumn{2}{|c|}{ Eigen value } & 16.11 & 2.25 & 1.95 & 1.45 & 1.16 & 1.0 \\
\hline \multicolumn{2}{|c|}{ Percentage of Value Explained } & 44.74 & 6.26 & 5.42 & 4.01 & 3.22 & 2.9 \\
\hline \multicolumn{2}{|c|}{ Cumulative percentage } & 44.74 & 50.99 & 56.41 & 60.42 & & \\
\hline
\end{tabular}

In analysing the responses of sportswear consumers regarding their store selection criteria, six factors; namely, sales assistance, store atmospherics, store appeal (interior/exterior), in-store induced, promotion/brand availability and store accessibility were extracted. The total variance explained by the extracted factors is $66.58 \%$, which indicates that the other $33.42 \%$ is accounted for by extraneous variables that do not constitute part of this study. The percentage of variance explained complies with Maholtra and Birks' (2007:121) prescription that the cumulative percentage of variance extracted by the factors should be at least $60 \%$.

\section{Discussion}

Factor one, labelled sales assistance, consisted of six items that accounted for $44.74 \%$ of the total variance explained. This factor involves a number of elements such as the appearance of sales personnel, sales personnel's willingness to assist customers, the treatment offered to customers, personalised attention and the ability to effectively and efficiently attend to customers' requests. As suggested by Moschis, Ferguson and Zhu (2011:796), the availability of store personnel is an important factor in the selection of apparel stores. Consistent with these findings, studies by Gundala (2010:71) and Clodfelter (2010:139) concluded that consumers usually patronise stores where they find experienced sales personnel who are friendly, supportive, attentive and courteous when shopping for clothing. Helpful and knowledgeable sales personnel in a store have a positive effect on consumers' perception of store image and that makes store personnel one of the crucial elements in retailing (Hu \& Jasper, 2006:41; Hu, 2011:99). As such, to have sufficient, well trained and skilled sales personnel in the retailing sector, especially the apparel sector creates a competitive advantage over those who lack in such provisions (Grewal, Baker, Levy \& Voss, 2003:265; Dalwadi, Rathod \& Patel, 2010:32). Ghosh et al. (2010:85) also concur that sales assistants in retail stores should have sufficient knowledge of the products offered, and must also be willing and capable of responding.

Factor two, labelled store atmospherics, consisted of six items that accounted for $6.26 \%$ of the explained variance. This factor focuses on aspects that relate primarily to the level of store ambience and how it influences sportswear store selection. A number of scholars (Du Preez et al., 2010:21; Petermans \& Van Ceempoel, 2010:33; Thenmozhi \& Dhanapal, 2011:22) also came up with similar findings in their studies, thereby confirming that store atmospherics and ambience characteristics are influential determinants of store choice. In an earlier study by Moye and Giddings (2002:274) it was found that store atmospherics which includes store interior (attractive, fashionable, stylish decorations, lightings, temperature) seem to have a positive direct influence on shopping behaviour in various clothing stores. Store design and decorations are also used as visual signals used to lure shoppers into stores (Nguyen \& LeBlanc, 2002:244). Hsu and Chang (2008:160) add that consumers typically may purchase certain products in stores that have a pleasing environment. Thang and Tan (2003:198) also suggest that pleasing store atmospherics which offer comfortable, fashionable, stylish and gratifications that contribute to customers' sense of well-being in the store tend to enhance consumer preferences for the store. Therefore, well-planned retail atmospherics factors should be established in order to create positive consumer behaviour towards the store and the kind of behaviour that can be linked to increased levels of browsing and increased levels of consumer spend in store (Noad \& Rogers, 2008:1004).

Factor three, labelled store appeal (interior/exterior) encompassed six items and accounted for $5.42 \%$ of the explained variance. The elements associated with this factor relate to the variety of brands marketed by the store, the appeal of in-store displays, the appeal of the entrance of the store, the appeal of the exit of the store, the proximity of the store in relation to others and the attractiveness of exterior design which shoppers interact with while visiting shopping malls. These aspects contribute to the uniqueness of the store. According to Tlapana (2009:12) a store that is able to 
communicate product information via in-store display actually assists consumers to make-informed purchase decisions. Even merchandise that is seen as less attractive is more likely to be purchased when displayed together with popular brands (Aspfors, 2010:38). Appealing store interiors and exteriors which are integrated with an appealing in-store display of various brands are therefore necessary factors that promote engagement from consumers (Moerloose, Antioco, Lindgreen \& Palmer, 2005:472).

Factor four, labelled in-store induced appeals, was composed of five items and accounted for $4.01 \%$ of the explained variance. In-store induced appeals incorporate issues such as the availability of gift vouchers, credibility of instore advertising, and mark-downs. In-store appeals are an important approach for alerting consumers about special offers and gift vouchers available. In line with this view, Hyllegard, Ogle \& Yan (2009:110) indicates that both in-store and out-of-store appeals have the potential of shaping the consumers purchase intentions. Jefkins (2000:5) suggests that retailers should implement in-store induced appeals which will present the most credible and persuasive selling message to the right prospects for the product or service at the lowest possible cost. Scott and Walker (2010:1106) also indicate that more customers can be drawn to the store via extensive in-store and out-of-store credible advertising. Chiliya, Herbst and Roberts-Lombard, (2009:074) are of the view that word-of-mouth (WOM) communication amongst black consumers is the most credible form of advertising. A price markdown is a strategy used by retailers to eliminate off season items and responding to competitive pressure (Fam, Merrilees, Richard, Jozsa, Li \& Krisjanous, 2011:172). As such, it is imperative for sportswear shop owners to ensure that both the internal as well as external designs of their shop are of such a standard that appeals to the targeted customers.

Factor five, labelled promotion/brand availability, comprised six items and accounted for $3.22 \%$ of the explained variance. The items loaded onto this factor include the timely announcement of sales, availability of special offers, the availability of exclusive brands and availability of branded labels. Kotler and Keller (2006:555) defined sales promotions as a diverse collection of incentives, designed to stimulate quicker and /or greater purchases of particular products or services. Promotion has also been perceived as one of the significant attributes of apparel store image (Visser et al., 2006:57; Van der Vvyer, 2008:79). According to Collins-Dodd and Lindley (2003) retailers could easily improve their image by promoting or marketing exclusive brands with a high image which could also open up huge opportunities to differentiate themselves from other retailers. Consumers are more likely to purchase from a retailer that runs promotions on some of their merchandise (Vipu, 2010:63). Research undertaken by Nazish, Rizvi and Malik (2011:302) also affirms that sales promotions have a positive impact on store selection and sales. It is therefore important for marketers to optimise promotional campaigns in order to boost the sales volumes of their brands.

Factor six, labelled store accessibility, comprised seven variables and accounted for $2.94 \%$ of the explained variance. This factor incorporates items that relate to the consumers' level of store convenience and accessibility as these two influences their shopping behaviour. The items loaded include onto this factor include store layout, the ease at which merchandise can be found, ease of movement within the mall, the amount of walking required, stores operating hours, and the position of aisles. These results are consistent with the results obtained in a study by Van der Vvyer, (2008:78) who found that the ease of finding merchandise and the amount of walking required were important to customers. For many shoppers, convenience is essential, the speed and ease that consumers can make contact with retailers (finding the merchandise they seek quickly) powerfully influence their retail choice (Bianchi, 2009:311). The location of the store may, in some cases, be the deciding factor for such consumers (Clodfelter, 2010:138; Kimani, Kendi, Wawire \& Fourier, 2012:60; Huang, Oppewal \& Mavondo, 2012:26). For example, consumers may select a store at shopping mall because of proximity with other stores. Time pressure and cost implications also drive consumers to seek accessible shopping. The closer the consumers are to a store, the greater the possibility to buy from that store (Prasad \& Aryasri, 2011:70). Ligas and Chaudhuri (2012:254) stressed that lack of convenient accessibility affect consumers' level of commitment to the store which might be reflected in store loyalty. Accessibility is therefore important for a retail outlet as it signifies convenience and reach for the store which allows consumers to shop easily.

\section{Reliabilities and Mean Ranking of Dimensions in Terms of Importance}

In addition to factor analysis, summated means were computed for each factor and ranked in terms of their importance. Table 3 reports on the means of the dimensions. 
Table 3: Reliabilities and mean ranking of dimensions

\begin{tabular}{|l|c|c|c|c|}
\hline \multicolumn{1}{|c|}{ Factors } & $\begin{array}{c}\text { Reliability } \\
\text { Cronbach alpha }\end{array}$ & Standard Deviation & Mean & Position in mean rank \\
\hline Factor 1: (Sales assistance) & 0.81 & 1.47 & 5.08 & 1 \\
\hline Factor 2: (Store atmospherics) & 0.79 & 1.43 & 4.86 & 6 \\
\hline Factor 3: (Store appeal) & 0.71 & 1.28 & 4.93 & 5 \\
\hline Factor 4: (In-store induced appeals) & 0.83 & 1.40 & 5.05 & 2 \\
\hline Factor 5: (Promotion/brand availability) & 0.74 & 1.20 & 4.98 & 3 \\
\hline Factor 6: (Store accessibility) & 0.77 & 1.25 & 4.95 & 4 \\
\hline Overall values & 0.76 & 1.43 & 4.98 & N/A \\
\hline 7= extremely important; 4= moderately important; 1= extremely unimportant \\
\hline
\end{tabular}

The mean scores for all the factors used in this study ranged between $(\bar{x}=4.86)$ and $(\bar{x}=5.08)$. These mean scores portray an average scoring between the 'moderately important' and 'very important' positions on the Likert scale. This suggests that all six factors were considered to be important by sports apparel consumers. A comparison of the factors also shows that store assistance $(\bar{x}=5.08)$ was ranked highest while store atmospherics $(\bar{x}=4.86)$ was ranked lowest. This finding suggests that among the six factors identified in the study, consumers of sports apparel perceive that sales assistance is the most important or significant factor whereas store atmospherics is the least important factor determining store choice. Noting the importance of these factors, efforts by sports apparel store managers should aim at monitoring and improving these factors in order to attract more customers.

\section{Test for Differences: Store Selection Criteria Gender}

In addition to the mean ranking of the store selection dimensions, it was necessary to establish whether there are any variations in terms of gender and the identified factors. Non-parametric tests were computed between the store choice dimensions and gender.

Table 4: Test for differences - store choice dimensions and gender

\begin{tabular}{|c|c|c|c|c|c|c|}
\hline Non-Parametric Test & Factor $1^{*}$ & Factor $2^{*}$ & Factor $3^{*}$ & Factor $4^{*}$ & Factor $5^{*}$ & Factor $6^{*}$ \\
\hline Mann-Whitney U Test & 27549.50 & 27485.00 & 28452.50 & 27337.00 & 28628.00 & 27039.50 \\
\hline Wilcoxon W & 54810.50 & 54746.00 & 55713.50 & 54598.00 & 55889.00 & 54300.50 \\
\hline$Z$ & -1.02 & -1.07 & -.439 & -1.168 & -.325 & -1.362 \\
\hline Asymp. Sig. & .303 & .284 & .660 & .243 & .745 & .173 \\
\hline
\end{tabular}

The Mann-Whitney $\mathrm{U}$ test revealed no significant differences in the store choice dimensions between males and females respondents as the $p$-value was $>0.05$ ( $p$-value $=0.303 ; 0.284 ; 0.660 ; 0.243 ; 0.745 ; 0.173$ ) among all dimensions respectively. It therefore seems that male and female respondents do not differ in terms of the presence of store personnel and their assistance, store atmospherics, the appeal of the store in terms of its interior/exterior designs and layout, in-store induced appeals, special promotions and famous brands and accessibility of the store. Consistent with this result, Birtwistle and Shearer (2001:14) and Gundala (2010:75) also found that gender does not significantly influence store choice among consumers. However, the findings of the current study contradict the results obtained by Torres, Summers \& Belleau (2001:209) as well as Otnes and McGrath (2001:132) who found that male shoppers consider different attributes while shopping for apparel when compared to female shoppers. The contradiction could be based on the fact that the later two studies by were not conducted among consumers of sports apparel, as does the current study.

\section{Limitations and Implications for Further Research}

The current study has some limitations, which should be considered. First, the sample was only recruited from three 
shopping malls located in one geo-spatial context; namely Gauteng Province. As such, it is important to note that this study is not entirely representative of all ethnic groups and regions or provinces. Second, due to the non-probability nature of sampling and the limitations in terms of the sample size, generalisability of the findings must be treated with caution. Third, this study used adapted questionnaires that were originally designed and intended for purposes and contexts that differ from those of this study. Finally, we acknowledge the general limitations that are associated with the quantitative design as used in this study.

Several implications for further study stem from this research. First, since the study focused on sports apparel, future studies should be extended on the purchase of products other than sports apparel. Second, similar studies could be conducted that include other regions of Gauteng, other provinces, other subcultures, social classes and lifestyles. Since the quantitative mode was adopted for this study, future studies could use the mixed method approach in which both qualitative and quantitative approaches are integrated. This could provide an in depth understanding of store selection criteria among consumers. Future direction on store selection criteria also requires further refinement of the survey instrument. In order to examine improvements to the instrument, longitudinal research could be conducted by replicating the study in similar settings over different time phases. This could provide updated insights on the changing shifts in store selection criteria among consumers of sports apparel.

\section{Conclusion}

The purpose of the study was to examine factors influencing the store selection choice among consumers of sports apparel in South Africa. The findings of this study revealed that there are six key store selection dimensions that play a crucial role in sportswear store selection. These are sales assistance, store atmospherics, store appeal, in-store induced appeals, promotion or brand availability and store accessibility. Among these six factors, sales assistance emerged as the most important factors and store atmospherics emerged as the least important factor to consumers of sports apparel. The study also revealed that gender has an insignificant impact in determining store choice.

The study is not without management implications. In the competitive retailing industry and continued economic pressure of the contemporary marketplace, store managers should continue to identify influential store selection dimensions that consumers perceive important when shopping. An understanding of what motivate shoppers to select one store amongst other stores, and the identification of in-store and out-of-store activities encourages consumers to stay loyal are critical to the success of retail businesses. Retailers should also acknowledge that there is a rising market with regard to consumers who are more demanding in terms of apparel purchase. Therefore, to sportswear retailers in particular, patronage levels may be enhanced considerably through continuous monitoring and expediting of the sportswear store selection dimensions identified in this study.

\section{References}

Aaker, D.A., Kumar, V. \& Day, G.S. (2007). Marketing research. 9th ed. Hoboken: John Wiley \& Sons.

Amine, A. \& Cadenat, S. (2003). Efficient retail assortment: a consumer choice evaluation perspective. International Journal of Retail \& Distribution Management, 31(10), 486-497.

Aspfors, E. (2010). Customer perception of service, store image and product assortment: from an interior store perspective. Unpublished Masters Degree Dissertation. Vaasa: Vaasa University of Applied Sciences.

Baker, J., Parasuraman, A., Grewal, D. \& Voss, G. B. (2002). The influence of multiple store environment cues on perceived merchandise value and patronage intentions. Journal of Marketing, 66(2), 120-141.

Baltas, G. \& Papastathopoulou, P. (2003). Shopper characteristics, product and store choice criteria: a survey in the Greek grocery sector. International Journal of Retail \& Distribution Management, 31(10), 498-507.

Berman, B. \& Evans, J.R. (2010). Retail management: a strategic approach. 11th ed. Upper Saddle River, New Jersey: Prentice-Hall.

Bianchi, C.C. (2009). Investigating consumer expectations of convenience-store attributes in emerging markets: evidence in Chile. Journal of International Consumer Marketing, 21, 309-320.

Birtwistle, G., \& Shearer, L. (2001). Consumer perception of five UK fashion retailers. Journal of Fashion Marketing \& Management, 5(1), 9-18.

Blackwell, R.D. \& Miniard, P.W. \& Engel, F.J. (2006). Consumer behaviour. 10th ed. Singapore: Thomson South-Western.

Broekemier, G., Marquardt, R. \& Gentry, J.W. (2008). An exploration of happy/sad and liked/disliked music effects on shopping intentions in a woman's clothing store service setting. Journal of Service Marketing, 22(1), 59-67.

Burns, A.C. \& Bush, R.F. (2010). Marketing research. $6^{\text {th }}$ ed. New Jersey: Pearson.

Carpenter, J.M. \& Brosdahl, D.J.C. (2011). Exploring retail format choice among US males. International Journal of Retail \& Distribution Management, 39(12), 886-898.

Chang, E.C. \& Luan, B. (2010). Chinese consumers' perception of hypermarket store image. Asia Pacific Journal of Marketing \& 
Logistics, 22(4), 512-527.

Chen-Yu, J.H. \& Seock, Y.K. (2002). Adolescents 'clothing purchase, information sources, and store selection criteria: a comparison of male/female and impulse/nonimpulse shoppers. Family \& Consumer Sciences Research Journal, 31(1), 50-77.

Chiliya N., Herbst, G. \& Roberts-Lombard, M. (2009). The impact of marketing strategies on profitability of small grocery shops in South Africa townships. African Journal of Business Management, 3(3), 70-79.

Churchill, G.A. \& Brown, T.J. (2007). Basic marketing research. $6^{\text {th }}$ ed. Mason: Thomson South-Western.

Collins-Dodd, C., Lindley, T. (2003). Store brands and retail differentiation: The influence of store image and store brand attitude on store own brand perceptions. Journal of Retailing \& Consumer Services, 10(6), 345-352.

Clodfelter, R. (2010). Retail buying: From basics to fashion. $3^{\text {rd }}$ ed. New York: Fairchild Books.

Dalwadi, R., Rathod, H.S. \& Patel, A. (2010). Key retail store determining consumers' perceptions: an empirical study on consumers of retail store located in Ahmedabad (Gujarat). South Indian Education Society (SIES) Journal of Management, 7(1), 20-34.

De Klerk, M.H. \& Lubbe, S. (2008). Female consumer's evaluation of apparel quality: exploring the importance of aesthetics. Journal of Fashion Marketing \& Management, 12(1), 36-50.

Du Preez, R., Visser, E. \& Van Noordwyk, H.J. (2008a). Store image: Towards conceptual model part 1. South African Journal of Industrial Technology, 34(2), 50-58.

Du Preez, R., Visser, E. \& Van Noordwyk, H.J. (2008b). Store image: Scale implementation part 3. South African Journal of Industrial Technology, 34(2), 69-78.

Fam, K.S., Merrilees, B., Richard, J.E., Jozsa, L., Li, Y. \& Krisjanous, J. (2011). In-store marketing: a strategic perspective. Asia Pacific Journal of Marketing \& Logistics, 23(2), 165-176.

Foxall, G.R. \& Yani-de-Soriano, M.M. (2005). Situational influences on consumers' attitudes and behaviour. Journal of Business Research, 58(4):518-525.

Hair, J. F., Black, B., Babin, B., Anderson, R. E., Tatham, R. L., \& Black, W. C. (2010). Multivariate data analysis: A global perspective. NY: Pearson Education Inc.

Hassan, Y., Muhammad, N. M. N., \& Abu Bakar, H. (2010). Influence of Shopping Orientation and Store Image on Patronage of Furniture Store. International Journal of Marketing Studies, 2(1), 175-184.

Hsu, J.L. \& Chang, K.M. (2008). Purchase of clothing and its linkage to family communication and lifestyles among young adults. Journal of Fashion Marketing \& Management, 12(2), 147-163.

Hsu M.K., Huang, Y. \& Swanson, S. (2010). Grocery store image, travel distance, satisfaction and behavioral intentions: evidence from a Midwest college town. International Journal of Retail \& Distribution Management, 38(2), 115-132.

$\mathrm{Hu}, \mathrm{H}$. (2011). Chinese consumers' store image formation and its impact on patronage behaviour. Academy of Marketing Studies Journal, 15(2), 83-102.

Hu, H. \& Jasper, C.R. (2006). Social cues in the store environment and their impact on store image. International Journal of Retail \& Distribution Management, 34(1), 25-48.

Huang, Y., Oppewal, H. \& Mavondo, F. (2012). The influence of ethnic attributes on ethnic consumer choice of service outlet. European Journal of Marketing, 47(5/6), 1-44.

Hyllergard, K., Ogle, J. \& Yan, N. (2009). The impact of advertising message strategy fair labour v. sexual appeal upon Gen Y consumers' intent to patronize an apparel retailer. Journal of Fashion Marketing \& Management, 13(1), 109-127.

Grewal, D., Baker, J., Levy, M. \& Voss, B.V. (2003). The effects of wait expectations and store atmosphere evaluations on patronage intentions in service-intensive retail stores. Journal of Retailing, 79(4), 259-268.

Gundala, R.R. (2010). Retail store image: a study of the Cyprus clothing industry. International Journal of Management \& Marketing Research, 3(3), 67-81.

Jefkins, F. (2000). Advertising. $4^{\text {th }}$ ed. London: Pearson Education Limited.

Kardes, F.K., Cline, T.W \& Cronley, M.L. (2011). Consumer behaviour: science and practice. Ohio: South-Western Cengage Learning.

Karpova, E., Hodges N. N. \& Tullar, W. (2007). Making sense of the market. An exploration of apparel consumption practices of the Russian consumer. Journal of Fashion Marketing \& Management, 11(1), 106-121.

Kim, Y. K. (2002). Consumer value: an application to mall and internet. International Journal of Retail \& Distribution Management, 30(12), 595-602.

Kimani, S.W., Kagira, E.K., Kendi, L., Wawire, C.M. \& Fourier, U.J. (2012). Shoppers perception of retail service quality: supermarkets versus small convenience shops (Dukas) in Kenya. Journal of Management \& Strategy, 3(1), 55-66.

Koksal, M.H. (2007). Consumer behaviour and preferences regarding children's clothing in Turkey. Journal of Fashion Marketing \& Management, 11(1), 69-81.

Kotler, P. \& Keller, K.L. (2006). Marketing management. $12^{\text {th }}$ ed. New Jersey: Prentice-Hall.

Kwon, W.S. \& Lennon, S.J. (2011). Assessing college women's associations of American speciality apparel brands. Journal of Fashion Marketing \& Management, 15(2), 242-256.

Kucukemiroglu, O. (1999). Market segmentation by using consumer lifestyle dimensions and ethnocentrism: an empirical study. European Journal of Marketing, 33(5/6), 470-487.

Lamb (Jr), C.W., Hair (Jr) J.F., Mcdaniel, C., Boshoff, C., Terblanche, N., Elliot, R. \& Klopper, H.B. (2010). Marketing. $4^{\text {th }}$ ed. Cape Town: Oxford University Press.

Leszczyc, P.T.L., Sinha, A. \& Timmermans, H.J.P. (2000). Consumer store choice dynamics: an analysis of the competitive market structure for grocery stores. Journal of Retailing, 76(3), 323-345. 
Levy, M. \& Weitz, B. A. (2007). Retailing management. $6^{\text {th }}$ ed. University of Florida: McGraw-Hill.

$\mathrm{Li}, \mathrm{Y}$. (2008). Chinese consumer's evaluation of multinational and domestic discount store image and store satisfaction. Unpublished Masters Degree Dissertation. Stillwater: Oklahoma State University.

Lu, Y. \& Rucker, M. (2006). Acquisition via single vs. multiple channels: College students' perspectives in the US and China. Journal of Retailing \& Consumer Services, 13(1), 35-50.

Ligas, M. \& Chaudhuri, A. (2012). The moderating roles of shopper experience and store type on the relationship between perceived merchandise value and willingness to pay a higher price. Journal of Retailing \& Consumer Services, 19(2), 249-258.

Lusch, R.F., Dunne, P.M. \& Carver, J.R. (2011). Introduction to retailing. Ohio: South-Western Cengage Learning.

Malhotra, N . K. (2010). Marketing research: An applied orientation. (6th ed) New Jersey: Prentice-Hall.

Maholtra, N. K. \& Birks, D. F. (2007). Marketing research: An Applied Approach. $3^{\text {rd }}$ ed. London: Prentice Hall.

Martineau, P. (1958). The personality of the retail store. Harvard Business Review, 36(1):47-55.

McKeever, K. (2011). Visual Merchandising. How to make your store sparkle this Christmas. [Online.] Available at <www.retailweek.com/store/visual merchandising. >. Accessed: 2012/08/26.

Moerloose, C., Antioco, M., Lindgreen, A. \& Palmer, R. (2005). Information kiosks: the case of the Belgian retail sector. International Journal of Retail \& Distribution Management, 33(6), 472-490.

Moore, M. \& Carpenter, J. (2006). The effect of price as a marketplace cue on retail patronage. Journal of Product \& Brand Management, 15(4), 265-271.

Morschett, D., Swobona, B. \& Foscht, T. (2005). Perception of store attributes and overall attitudes towards grocery retailers: the role of shopping motives. International Review of Retail, Distribution \& Consumer Research, 15(4), 423-447.

Moschis, G.P., Ferguson, J.L. \& Zhu, M. (2011). Mature consumers' selection of apparel and footwear brands and department stores. International Journal of Retail \& Distribution Management, 39(10), 785-801.

Moye, L.N. \& Giddings, V.L. (2002). An examination of the retail approach-avoidance behaviour of older apparel consumers. Journal of Fashion Marketing \& Management, 6(3), 259-276.

Nazish, S., Rizvi, Z. And Malik, S. (2011). Impact of sales promotion on organizations' profitability and consumer's perception in Pakistan. Interdisciplinary Journal of Contemporary Research in Business, 3(5), 296-310.

Nguyen, N. \& Leblanc, G. (2002). Contact personnel, physical environment and the perceived corporate image of intangible services by new clients. International Journal of Service Industry Management, 13(3), 242-262.

Noad, J. \& Rogers, B. (2008). The importance of retail atmospherics in B2B retailing: the case of BOC. International Journal of Retail \& Distribution Management, 36(12), 1002-1014.

Otnes, C. \& Mcgrath, M. A. (2001). Perceptions and realities of male shopping behaviour. Journal of Retailing, 77(1), 111-137.

Oates, B., Shufeldt, L. \& Vaught, B. (1996). A psychographic study of the elderly and retail store attributes. Journal of Consumer Marketing, 13(6), 14-27.

Oh, J., Fiorito, S.S., Cho, H. \& Hofacker, C.F. (2008). Effects of design factors on store image and expectation of merchandise quality in web-based store. Journal of Retailing \& Consumer Services, 15(4), 237-249.

Pan, Y. \& Zinkhan, G. (2006). Determinants of retail patronage: a meta-analytical perspective. Journal of Retailing, 82(3), $229-243$.

Petermans, A. \& Van Cleempoel, K. (2010). Designing a retail store environment for the mature market: a European perspective. Journal of Interior Design, 35(2), 21-36.

Prasad, C.J. \& Aryasri, A.R. (2011). Effect of shopper attributes on retail format choice behaviour for food and grocery retailing in India. International Journal of Retail \& Distribution Management, 39(1), 68-86.

Rigopoulou, I.D. \& Tsiotsou, R.H. (2008). Shopping orientation-defined segment based on store-choice criteria and satisfaction. Journal of Marketing Management, 24(9/10), 979-995.

Saraswat, A., Mammen, T., Aagja, J.P. \& Tewari, R. (2010). Building store brands using image differentiation. Journal of Indian Business Research, 2(3), 166-180.

Schiffman, L.G. \& Kanuk, L.L. (2009). Consumer Behaviour. 9th ed. New Jersey: Pearson Education International.

Scott, P. \& Walker, J. (2010). Advertising, promotion, and the competitive advantage of interwar British department stores. Economic History Review, 63(4), 1105-1128.

Semeijn, J., Van Riel, A.C.R. \& Ambrosini, A.B. (2004). Consumer evaluations of store brands: effects of store image and product attributes. Journal of Retailing \& Consumer Research, 11(4), 247-258.

Sherman, E., Mathur, A. \& Smith, R.B. (1997). Store environment and consumer purchase behaviour: mediating role of consumer emotions. Psychology \& Marketing, 14(4), 361-378.

Sinha, P.K. \& Banerjee, A. (2004). Store choice behaviour in an evolving market. International Journal of Retail \& Distribution Management, 32(10), 482-494.

Sinha, P.K., Banerjee, A. \& Uniyal, D.P. (2002). Deciding where to buy: store choice behaviour of Indian shoppers. Vikalpa Management Journal, 27(2), 13-28.

Torres, I.M, Summers, T.A. \& Belleau, B.D. (2001). Men's shopping satisfaction and store preferences. Journal of Retailing \& Consumer Services, 8(4):205-212.

Tlapana, T.P. (2009). Store layout and its impact on consumer purchasing behaviour at convenience stores in Kwa-Mashu. Unpublished Masters Degree Dissertation, Masters. Durban: Durban University of Technology.

Thang, D.C.L. \& Tan, B.L.B. (2003). Linking consumer perception to preference of retail stores: an empirical assessment of the multiattributes of store image. Journal of Retailing \& Consumer Service, 10(4), 193-200. 
Thenmozhi, S.P. \& Dhanapal, D. (2012). Store choice behaviour in retail outlets. Global Management Review, 6(2):10-23.

Van Der Vyver, J. (2008). The importance of store image dimensions in apparel retail: Customer and management perceptions. Unpublished M.Com Dissertation. Cape Town: University of Stellenbosch, Stellenbosch.

Van Waterschoot, W., Sinha, P.K., Van Kenhove, P. \& De Wulf, K. (2008). Consumer learning and its impact on store format selection. Journal of Retailing \& Consumer Services, 15, 194-210.

Venter, P.F. \& Dhurup, M. (2005). Consumer perceptions of supermarket service quality: scale development and validation. South African Journal of Economic \& Management Science, 8(4), 424-436.

Vipul, P. (2010). Impact of demographic factors on consumer response to sales promotions: an empirical study. Advances in Management, 3(10):60-65.

Visser, E., Du Preez, R. \& Van Noordwyk, H.J. (2006). Importance of apparel store image attributes: perceptions of female consumers. South African Journal of Industrial Technology 32(3):49-62.

Wiid, J. \& Diggines, C. (2009). Marketing research. Cape Town: Juta.

Wirtz, J., Mattila, A.S. \& Tan, R.L.P. (2007). The role of arousal congruency in influencing consumers' satisfaction evaluations and instore behaviors. International Journal of Service Industry Management, 18(1), 6-25.

Zikmund, W.G. \& Babin, B.J. (2010). Essentials of marketing research. $4^{\text {th }}$ ed. Ohio: South-Western Cengage Learning. 